\title{
Editorial
}

\section{Eroding Mutual Trust in an European Criminal Justice Area without Added Value}

With the arrival of the Treaty on European Union an Area of Freedom Security and Justice was created in which there would be no borders anymore. In a single judicial area the old borders between the Member States would gradually disappear. This would enhance cooperation between the Member States, make it easier to assist each other, allow for free movement of judicial decisions and fight impunity. It was also intended to strengthen the rights of the individual citizen in the criminal justice system, be it an accused, convicted or victim.

Case law of the Court of Justice of the last years has done the opposite. It has raised the thresholds for cooperation between the Member States by creating more formalities, causing delay and without strengthening legal remedies for the citizen. On two rather important aspects, surrender among the Member States on the basis of the EAW is now more complicated than extradition was before 2004. Whereas Member States' authorities are confronted with more formalities, the citizen does not profit from it. He is just a pawn in the game between authorities. In this contribution I will analyse the consequences of this. I will also address the question what this may lead to and what potential solutions for the problems sketched are. Circumstances

At first sight, the judgement in the case of Aranyosi and Căldăraru seemed to bring good news for improving the detention circumstances in some Member 
States. ${ }^{1}$ On reflection, there is little evidence that it does. What is clear, is that the Court's rules undermine mutual trust, cause delay, do not contribute to social integration and may lead to impunity. But first back to what the Court stated.

In the Aranyosi-case the Court stated that executing judicial authorities might postpone surrender to another Member State in case there is a risk of being subjected to prison conditions violating Article 4 Charter. Following case law of the ECtHR, it stated that the prevention of absolute rights violations trumps mutual recognition. It was remarkable that the Court did this, because it could easily have decided to keep the line of Melloni, ${ }^{2}$ in which it held that the Framework Decision on the EAW has a closed list of grounds for refusal and no new ones may be added. It went beyond that in Aranyosi, because of the absolute character of the rights at stake: life or protection against torture (Article 4 Charter). As a result of which it effectively added a new extralegal ground for refusal to the Framework Decision. In doing so, it transfers the responsibility for creating conditions of detention that respect Article 4 Charter from the authorities responsible for that detention to the authorities of another Member State that might surrender a requested person to the former. ${ }^{3}$ The latter executing authority does not detain the person and cannot change the circumstances itself. As to the detention circumstances it is quite powerless. The Court does not address the direct responsibility of the authorities that will detain the requested person. ${ }^{4}$ I consider that to be rather strange in a single European area. The Court regards rights and obligations not as applicable for the citizen in a commonly responsible area, but as relevant in the relationship individual versus one Member State (in concreto: the Member State having custody over the person) only.

1 Nina Peršak, The Rule of Law and European Criminal Law in Interaction, 27 European Journal of Crime, Criminal Law and Criminal Justice 2019, p. 1-11.

2 ECJ 26 February 2013, Case C-399/11, in the proceedings Stefano Melloni v Ministerio Fiscal.

3 ECJ 15 October 2019, Case C-128/18, in the proceedings relating to the execution of a European arrest warrant issued for Dumitru-Tudor Dorobantu, par. 81: "the executing judicial authorities are still bound to undertake an individual assessment of the situation of each person concerned, in order to satisfy themselves that their decision on the surrender of that person will not expose him, on account of those conditions, to a real risk of inhuman or degrading treatment within the meaning of Article 4 of the Charter."

4 In Piotrowski, the Court did state the primary responsibility of the issuing Member State, but it did not draw consequences from it: "Nevertheless, in so far as proceedings relating to a European arrest warrant are concerned, observance of those rights falls primarily within the responsibility of the issuing Member State, which must be presumed to be complying with EU law, in particular the fundamental rights conferred by that law". ECJ 23 January 2018, Case C-367/16, in proceedings relating to the execution of a European arrest warrant issued against Dawid Piotrowski, par. 5 . 
A key element of the reasoning by the Court is that: "Thus, when implementing EU law, the Member States may, under EU law, be required to presume that fundamental rights have been observed by the other Member States, so that not only may they not demand a higher level of national protection of fundamental rights from another Member State than that provided by EU law, but also, save in exceptional cases, they may not check whether that other Member State has actually, in a specific case, observed the fundamental rights guaranteed by the European Union (...)." ${ }^{5}$ However, the absolute character of the rights at stake, such as Article 4 Charter, may change that assumption. In such a case, the Court allows the executing Member State to ask for more information. That information may relate to the prison(s) in which the requested person will be detained. For the Court it means that the executing "authorities are solely required to assess the conditions of detention in the prisons in which, according to the information available to them, it is actually intended that the person concerned will be detained, including on a temporary or transitional basis. The compatibility with the fundamental rights of the conditions of detention in the other prisons in which that person may possibly be held at a later stage is, in accordance with the case-law referred to in paragraph 66 of this judgment, a matter that falls exclusively within the jurisdiction of the courts of the issuing Member State."6 Why is that so?

The consequence of the Court's case law is now that the issuing Member State will indicate a prison in which the requested person will be received, in which the circumstances are undisputed. The predictable follow up questions were immediately referred to the Court: how long should the issuing Member State keep the requested person in that good prison? It was here that the Court realized that if it were to require that the issuing Member State should guarantee good prison conditions for the whole period of detention, it would basically create a monitoring system, by which one Member State (executing) monitors the other (issuing), which could endure for years, depending on the length of the sentence imposed. ${ }^{7}$ So it answered somewhat vaguely that the information should relate to the place of which it is actually intended to detain

5 ECJ 25 July 2018, Case C-220/18 PPU, in the proceedings relating to the execution of a European arrest warrant issued against ML, intervener: Generalstaatsanwaltschaft Bremen, par. 50.

6 ECJ 25 July 2018, Case C-220/18 PPU, in the proceedings relating to the execution of a European arrest warrant issued against ML, intervener: Generalstaatsanwaltschaft Bremen, par. 87 .

7 In the ML case, the Court regarded the 78 questions on prison conditions asked by the Bremen Court because of their number and scope unacceptable. ECJ 25 July 2018, Case C-220/18 $\mathrm{PPU}$, in the proceedings relating to the execution of a European arrest warrant issued against ML, intervener: Generalstaatsanwaltschaft Bremen, par. 103. 
the requested person. It thus emphasizes foreseeable effects on the short term. ${ }^{8}$ Although the Court underlines in Dorobantu that it must relate to circumstances of that individual requested person, the criteria mentioned relate to circumstances generally applicable in the prison concerned. ${ }^{9}$ This makes the guarantee to a formality in which politically correct answers will follow. Also the fact that the Court instructs Member States that postponement and raising further questions is a possible outcome, but not a final refusal, contributes to a scenario in which formal questions are raised and desired answers will be given. The message to Member States having difficulties with prison conditions is: make sure you have a good prison to keep EAW prisoners in the first weeks and then you can do as you please. This is a strange reasoning if absolute rights are concerned. Absolute rights do not apply in just a limited period of time, but always, anytime. ${ }^{10}$ Or does the Court regard the fact that a prisoner will survive a few weeks then as evidence that absolute rights were not violated and that the risks are thus gone? If that were the case, it brings us back to square one: why not trust the issuing Member State before executing the EAW that its prison conditions will not violate Article 4 Charter? All Member States promised to do that and are bound by this obligation.

Because of the absolute character of the violations in a common area without borders, I think a more principled and far less formalistic approach must be taken.

In Aranyosi the Court held: "It must, in that context, be noted that recital 10 of the Framework Decision states that the implementation of the mechanism of the European arrest warrant as such may be suspended only in the event of serious and persistent breach by one of the Member States of the principles referred to in Article $2 \mathrm{TEU}$, and in accordance with the procedure provided for in Article 7 TEU."11 Is the breach of absolute human rights not a situation that must lead to the procedure described by Article 7 TEU? The

It thus prevented the introduction of a new speciality rule meaning that the issuing Member State is only entitled to detain the requested person in the prison that received approval before surrender. See Article 27(2) Framework Decision 2002/584 for the right to prosecute or execute only for those offences for which surrender has been granted. ECJ 15 October 2019, Case C-128/18, in the proceedings relating to the execution of a European arrest warrant issued for Dumitru-Tudor Dorobantu, par. 50-55.

10 However, the Court states that "to assess the conditions of detention in all the prisons in which the individual concerned might be detained in the issuing Member State would be clearly excessive." ECJ 15 October 2019, Case C-128/18, in the proceedings relating to the execution of a European arrest warrant issued for Dumitru-Tudor Dorobantu, par. 65 .

11 ECJ 5 April 2016, Joined Cases C-404/15 and C-659/15 PPU, in proceedings relating to the execution of European arrest warrants issued in respect of Pál Aranyosi (C-404/15), Robert Căldăraru (C-659/15 PPU), par. 81. 
finding that a requested person faces prison conditions equal to torture has an impact beyond the isolated hypothetical (hypothetical because he is still not in those circumstances) case as it is based on the conditions generally applicable to all prisoners in the relevant prison. I am afraid the Court circumvents the real problems at stake. Unlike the requested person, still safe in the executing Member State, the other prisoners are already been deprived of their absolute rights in the detention facility of the issuing Member State. The logical consequence of a finding that there is real risk of danger to life of torture for an individual to be surrendered to a prison, is that other prisoners are already being tortured and everything must be done to end that situation with regard to all prisoners. ${ }^{12}$ It is rather arbitrary to create an ad hoc arrangement for a requested person who is not even in the dangerous Member State and pay no attention at all to the prisoners already held in these very same deplorable circumstances. ${ }^{13}$ The Court follows the case law of the ECtHR on prison conditions. However, a few important differences must be noted. Whereas the ECtHR deals with individual complaints concerning real but past situations, the ECJ is called to judge before absolute rights might be impaired. That completely different situation ought to lead to a follow up that prevents all infringements of absolute rights in the given prison conditions, not just those concerning one lucky person.

In the case of Poltorak the Court dealt with the concept of the issuing judicial authority and held that it had an autonomous European notion: "the term 'judicial authority', contained in Article 6(1) of the Framework Decision, requires, throughout the Union, an autonomous and uniform interpretation, which, in accordance with the settled case-law of the Court, must take into account the terms of that provision, its context and the objective of the

\footnotetext{
12 The arbitrariness is also found in the fact that Member States see no problem in transferring prisoners (on the basis of Framework Decision 2008/909) to their state of origin, despite a deplorable situation in the prison. The explanation is that in the issuing Member State the authority involved is the executive and that in the executing Member State the court that decides on the enforcement of the decision will certainly not regard prison conditions in its own country as sub-standard; it sends convicts to it every day!

13 It may lead to double standards or dual criminal justice systems. See Miguel João Costa, Extradition Law. Reviewing Grounds for Refusal from the Classic Paradigm to Mutual Recognition and Beyond, European Criminal Justice Series, Brill Leiden 2020, p. 567-568.
} 
Framework Decision."14 Initially, this related to the question of whether a police authority could be regarded as a judicial authority. Subsequent case law evolved to an unprecedented level of technicalities.

Despite a common practice in the Member States of more than half a century in extradition and since 2004 also in EAW cases a prosecutor is no longer without further ado regarded as a competent judicial authority. Advocate General Campos Sánchez-Bordona even argued on the basis of the legislative history that it was never meant to have the public prosecutor included. ${ }^{15}$

The Court regards an arrest warrant as a judicial decision issued by a judicial authority. ${ }^{16}$ Apparently, the Court wishes to have an independent judge confirming a warrant issued by a prosecutor: "In that context, where a European arrest warrant is issued with a view to the arrest and surrender by another Member State of a requested person for the purposes of conducting a criminal prosecution, that person must have already had the benefit, at the first stage of the proceedings, of procedural safeguards and fundamental rights, the protection of which it is the task of the judicial authorities of the issuing Member State to ensure, in accordance with the applicable provisions of national law, for the purpose, inter alia, of adopting a national arrest warrant (judgment of 1 June 2016, Bob-Dogi, C-241/15, EU:C:2016:385, paragraph 55). The European arrest warrant system therefore entails a dual level of protection of procedural rights and fundamental rights which must be enjoyed by the requested person, since, in addition to the judicial protection provided at the first level, at which a national decision, such as a national arrest warrant, is adopted, there is the protection that must be afforded at the second level, at which a European arrest warrant is issued, which may occur, depending on the circumstances, shortly after the adoption of the national judicial decision (judgment of 1 June 2016, Bob-Dogi, C-241/15, EU:C:2016:385, paragraph 56). As regards a measure, such as the issuing of a European arrest warrant, which is capable of impinging on the right to liberty of the person concerned, enshrined in Article 6 of the Charter of Fundamental Rights of the European Union, that protection means that a decision meeting the requirements inherent in effective judicial protection should be adopted, at least, at one of the two levels of that

\footnotetext{
14 ECJ 10 November 2016, Case C-452/16 PPU, in the proceedings relating to the execution of a European arrest warrant issued against Krzystof Marek Poltorak, par. 32.

15 Opinion of Advocate General Campos Sánchez-Bordona of 30 April 2019, Case C-509/18, in proceedings relating to the execution of a European arrest warrant issued in respect of PF, par. $37-46$.

16 ECJ 27 May 2019, Joined Cases C-508/18 and C-82/19 PPU, in proceedings relating to the execution of European arrest warrants issued in respect of OG (C-508/18), PI (C-82/19 PPU), par. 46 .
} 
protection. It follows that, where the law of the issuing Member State confers the competence to issue a European arrest warrant on an authority which, whilst participating in the administration of justice in that Member State, is not a judge or a court, the national judicial decision, such as a national arrest warrant, on which the European arrest warrant is based, must, itself, meet those requirements." ${ }^{17}$

This raises the question whether it is the authority as such that is the issue, or that a warrant must be authorized by a judge and cannot be solely based on a prosecutorial decision. This ambiguity about the reasons for this requirement has severely contributed to uncertainty with the Member States' authorities, ${ }^{18}$ it led to delays and to many references for a preliminary ruling. ${ }^{19}$ The whole debate circles around the use of "judicial authority' in Article 6 (1) Framework Decision. The Court held that the term requires an autonomous and uniform interpretation. ${ }^{20}$

Concerning the need for judicial oversight the question emerged whether it makes a difference whether it concerns cases of prosecution warrants or execution cases. Advocate General Campos Sánchez-Bordona held that judicial oversight undertaken at the time the national arrest warrant (NAW) is issued cannot, by its very nature, satisfy 'the requirements inherent in effective judicial protection' referred to in paragraph 75 of the judgment in OG and PI (Public Prosecutors of Lübeck and of Zwickau), in that such protection is always at the request of the interested party and is provided through a procedure in which he has been able to intervene and take part in the exercise of his right to a defence. ${ }^{21} \mathrm{He}$ argues that this also applies to warrants for execution, as there may still be a question of whether it is proportional to issue the EAW, also in view of the impact it has on the personal life of the convicted and the

17 ECJ 27 May 2019, Case C-509/18, in proceedings relating to the execution of a European arrest warrant issued in respect of $\mathrm{PF}$, par. 44-47.

18 Opinion of Advocate General Campos Sánchez-Bordona of 30 April 2019, Case C-509/18, in proceedings relating to the execution of a European arrest warrant issued in respect of PF, par. $33-36$.

19 Request for a preliminary ruling from the cour d'appel d'Aix-en-Provence (France) lodged on 5 November 2019 - MN, (Case C-813/19). C-625/19 PPU) and France (Cases C-566/19 PPU and C-626/19 PPU); Request for a preliminary ruling from the Eparchiako Dikastirio Larnakas (Cyprus) lodged on 22 February 2019 - Cyprus Central Authority v GA (Case C-154/19); Reference for a preliminary ruling from the High Court (Ireland) made on 7 November 2018 - Minister for Justice and Equality v ND (Case C-685/18);

20 ECJ 27 May 2019, Case C-509/18, in proceedings relating to the execution of a European arrest warrant issued in respect of PF, par. 28.

21 Opinion of Advocate General Campos Sánchez-Bordona of 26 November 2019, Case C-627/19 PPU, Openbaar Ministerie v ZB., par. 19. 
possibility that the case may now be more suitable for a transfer of the judgement. The Advocate General suggests that court proceedings must be instituted. What is required is that either at the moment the national warrant is used or when the EAW is issued effective judicial protection should exist. In the opinion of the Advocate General this must be there before the EAW is issued. $^{22}$

In another case the Court had to answer the question of whether the fact that a public prosecutor's office is required to act on instruction preclude it from effectively issuing a European arrest warrant even in the case where that decision is subject to a comprehensive judicial review prior to the execution of the European arrest warrant? The Court held that it requires endorsement by a court which reviews independently and objectively, having access to the entire criminal file to which any directions or instructions in a specific case from the executive are added, the conditions of issue and the proportionality of those arrest warrants, thus adopting an autonomous decision which gives them their final form. ${ }^{23}$

The Court has framed the notion of "judicial authority" as a protection issue, despite the fact that EAW proceedings are not a criminal proceeding. What is the legal basis for a norm stating that an arrest warrant should have judicial overview before issuing? The judgement also raises even more broader questions. What rule is violated in a criminal justice system in which there is political influence on the criminal policy of the state? Does the prosecution need to be equally independent as a judge or a court?

In raising the bar for issuing authorities, the Court undermines mutual trust in authorities. The dual level of protection, as introduced by the Court, reinforces that two procedures will be necessary, one in the issuing Member State, before the EAW is issued, and another in the executing Member State, when it must be executed. According to the Court, the requested person would thus benefit from effective judicial protection. Is that so? The accused/ convicted person is not there when the EAW is issued, ${ }^{24}$ so he has no possibility at all to

22 Opinion of Advocate General Campos Sánchez-Bordona of 26 November 2019, Joined Cases C-566/19 PPU and C-626/19 PPU, Parquet général du Grand-Duché de Luxembourg v JR (Request for a preliminary ruling from the Cour d'appel (Chambre du conseil) (Court of Appeal (Investigation Chamber), Luxembourg)) and Openbaar Ministerie v YC, par. 93.

23 ECJ 9 October 2019, Case C-489/19 PPU, request for a preliminary ruling under Article 267 TFEU from the Kammergericht Berlin (Higher Regional Court, Berlin, Germany), made by decision of 26 June 2019, received at the Court on the same date, in the proceedings relating to the execution of a European arrest warrant issued against $\mathrm{NJ}$, in the presence of: Generalstaatsanwaltschaft Berlin, par. 49.

24 The Advocate General noted this circumstance, but did not draw any consequences from it. Opinion of Advocate General Campos Sánchez-Bordona of 30 April 2019, Joined Cases 
challenge it and bring his legal arguments forward. At a later stage, when being arrested and brought before a judge, he will have that opportunity. ${ }^{25}$ Whereas the Court rightly reminds Member States on a regular basis to conduct trials in the presence of the accused, ${ }^{26}$ as he is entitled to on the basis of Directive 2016/343 on the Presumption of Innocence and the Right to be Present, it does the opposite when issuing an EAW. It insists on a procedure before a court knowing that the requested person will never be there. ${ }^{27}$

As a consequence of its definition of a judicial decision and judicial authority, the Court takes issue with the fact that a prosecutor may receive instructions from a political body. ${ }^{28}$ When that generally is the case, a prosecutor would no longer be independent enough to issue an EAW all by himself. The Court hereby neglects that it belongs to the constitutional traditions of some Member States (and is at the same time completely absent in other) that the prosecution is interwoven with the executive. In some Member States, the Minister for Justice may even formulate the criminal policy of a state together with the Prosecution service. In many Member States, the execution of irrevocable judgements takes place by the executive, without a role of the judiciary.

C-508/18 and C-82/19 PPU, in proceedings relating to the execution of European arrest warrants issued in respect of OG (C-508/18), PI (C-82/19 PPU), par. 73 .

25 In cases of EAWs for execution of a sentence, it is simply impossible to redebate the need of deprivation of liberty. The convicting court made that assessment already in its verdict imposing a prison sentence.

26 See extensively Kei Hannah Brodersen, Vincent Glerum and André Klip, The European Arrest Warrant and In Absentia Judgments, Eleven Publishers 2020, Maastricht Law Series 12.

27 There are six Directives that strengthen the rights of the defence: Directive 2010/64 on Interpretation and Translation; Directive 2012/13 on the Right to Information; Directive 2013/48 on the Right of Access to a Lawyer; Directive 2016/343 on the Presumption of Innocence and the Right to be Present; Directive 2016/80o on Procedural Safeguards for Accused Children; Directive 2016/1919 on Legal Aid. All of which are also applicable in European Arrest Warrant proceedings (see their Articles 1). There is one noticeable exception for the right to be present. Directive 2016/343 on the Presumption of Innocence and the Right to be Present is not applicable in European Arrest Warrant proceedings.

28 According to the Advocate General it arises "rather from the legislative choices made in the Framework Decision to de-politicise the EAw procedure as compared to the classic extradition procedure." See Opinion of Advocate General Campos Sánchez-Bordona of 30 April 2019, Joined Cases C-508/18 and C-82/19 PPU, in proceedings relating to the execution of European arrest warrants issued in respect of OG (C-508/18), PI (C-82/19 PPU), par. 89. In my opinion, the Court has come to this conclusion based on wrong assumptions. The assumption is that it was intended by the drafters to de-politicize decision-making in extradition. That as such is correct, but it related to the executing authority, NOT to the issuing authority. Governments, ministers for justice should no longer have a say in the decision to grant or refuse extradition. 
To require full independence from the government raises new questions and calls for new procedures. Is this applicable to EAW only? Does it also apply to transfer of prisoners, which is in most Member States an exclusively executive decision? What about the European Investigation Order or police cooperation, which may also lead to coercive measures, infringing rights of individuals?

I personally think that the Court could place more trust in the issuing authorities and should not require executing authorities to investigate the degree of independence of the issuing authorities. The current Court's case law makes cooperation less effective, does not facilitate it, but delays cooperation, reinstates borders between Member States and undermines confidence. The Court's case law treats human rights values as a variety of the ECHR, not as rights with a different specific protection deriving from the Area of Freedom Security and Justice.

\section{Conclusion}

In Aranyosi the Court held: "The Framework Decision thus seeks, by the establishment of a new simplified and more effective system for the surrender of persons convicted or suspected of having infringed criminal law, to facilitate and accelerate judicial cooperation with a view to contributing to the attainment of the objective set for the European Union to become an area of freedom, security and justice, founded on the high level of confidence which should exist between the Member States". 29

For a single judicial area, it will be necessary that legal borders are abolished, instead of being upheld by the Court. The arbitrary selection of a handful of EAW cases in which citizens temporarily profit from the area through tailor-made individual privileges leads to unequal treatment among prisoners. To attempt to raise prison conditions via further questions in EAW proceedings leads to window dressing, formalities for authorities and no real chances that are felt by the persons most concerned. Most criminal proceedings are regular proceedings without any international dimension in which no cooperation is needed. It is there that the minimum rights count most and that guidance from the Court is needed on the consequences of violations in the

29 ECJ 5 April 2016, Joined Cases C-404/15 and C-659/15 PPU, in proceedings relating to the execution of European arrest warrants issued in respect of Pál Aranyosi (C-404/15), Robert Căldăraru (C-659/15 PPU), par. 76 . 
pending criminal trial. ${ }^{30}$ If the Court were to do that, it would strengthen the rights of individuals in reality on the ground in all Member States and make formalities before executing EAWs and other cooperation redundant. Cooperation proceedings between Member States are the off spin of national criminal proceedings and not vice versa. Should the Court continue to focus on cooperation issues only, it will contribute to the existence of two separate legal regimes: one for a small number of cooperation cases and another with fewer safeguards for the large majority of criminal proceedings. Only when the Court changes its focus from cooperation situations to regular criminal proceedings and detention circumstances it may effectively create a single European Criminal Justice Area and add a protection different from what is there already on the basis of the ECHR.

\section{André Klip}

Professor of Criminal Law and Criminal Procedure, Law Faculty, Maastricht University, Maastricht, the Netherlands andre.klip@maastrichtuniversity.nl

30 See André Klip, Violations of Defence Rights' Directives, 27 European Journal of Crime, Criminal Law and Criminal Justice 2019, p. 271-281. 